\title{
Effect of Sintering Temperature on
} Structural and Morphological Properties of Europium (III) Oxide Doped Willemite

\author{
Nur Fatin Syamimi, ${ }^{1,2}$ Khamirul Amin Matori, ${ }^{1,2}$ Way Foong Lim, \\ Sidek Abdul Aziz, ${ }^{1}$ and Mohd Hafiz Mohd Zaid ${ }^{1}$ \\ ${ }^{1}$ Department of Physics, Faculty of Science, Universiti Putra Malaysia, Serdang, Selangor 43400, Malaysia \\ ${ }^{2}$ Materials Synthesis and Characterization Laboratory (MSCL), Institute of Advanced Technology (ITMA), \\ Universiti Putra Malaysia, Serdang, Selangor 43400, Malaysia
}

Correspondence should be addressed to Khamirul Amin Matori; khamirul@upm.edu.my

Received 11 September 2014; Accepted 17 December 2014; Published 31 December 2014

Academic Editor: Pedro D. Vaz

Copyright (C) 2014 Nur Fatin Syamimi et al. This is an open access article distributed under the Creative Commons Attribution License, which permits unrestricted use, distribution, and reproduction in any medium, provided the original work is properly cited.

Willemite- $\left(\mathrm{Zn}_{2} \mathrm{SiO}_{4^{-}}\right)$based glass ceramics doped with various amounts of europium oxide $\left(\mathrm{Eu}_{2} \mathrm{O}_{3}\right)$ were prepared by solid state melting and quenching method. Effect of sintering temperature $\left(600-1000^{\circ} \mathrm{C}\right)$ on structural and morphological properties of the doped samples was investigated. Phase composition, phase evolution, functional groups, and microstructure analysis were, respectively, characterized using X-ray diffractometer (XRD), fourier transform infrared spectroscopy, field emission scanning electron microscopy (FE-SEM), and energy-dispersive X-ray. XRD analysis detected the presence of rhombohedral crystalline phase in the doped samples sintered at different temperatures. FE-SEM and bulk density results confirmed that doping of the willemite with $\mathrm{Eu}_{2} \mathrm{O}_{3}$ effectively enhanced densification. The microstructural analysis of the doped samples showed that the average grain size increased with the increase of sintering temperature.

\section{Introduction}

During the past few years, rare earth materials have been giving satisfactory accomplishment in the ceramic industry $[1,2]$. To date, only small percentage of the rare earth materials have been consumed in the production of ceramic materials. However, the function of the rare earth materials remains unclear and is important to be further explored [35]. Rare earth materials have been also doped with inorganic phosphor (willemite) based glass ceramics for potential applications in photonic devices, next generations flat panel displays (FPD) [6-9], optical amplifiers [10], and phosphors [11]. The reason for using the willemite-based glass ceramics as the host materials for doping is the high quantum efficiency, super chemical and thermal stability, water resistance, and low cost. By doping the rare earth elements into the willemite-based glass ceramics, the characteristics of white light under UV excitation [12] could be studied.
Thus far rare earth doped willemite-based glass ceramics have been widely used as the activators in various phosphors. Among these, europium oxide- $\left(\mathrm{Eu}_{2} \mathrm{O}_{3}-\right)$ doped compounds, which emit intense red light, have been broadly used as the phosphor materials due to the occurrence of electronic transition among the $4 \mathrm{f}^{n}$ inner shell energy levels [13-15]. Zinc silicate has an increasing attention for its potential as a phosphor host and glass ceramic because of its high temperature stability as a ceramic pigment $[16,17]$. There has been also a broad interest towards its luminescence, crystallography, and application as industrial materials. Many efforts have been made by researchers to produce pure willemite and willemite doped with various rare earth materials. However, there is a lack of work on studies of willemite that are obtained from waste materials.

In this paper, we report the synthesis of $\mathrm{Eu}_{2} \mathrm{O}_{3}$ doped willemite-based glass ceramic using waste materials that were prepared with different weight percentages (1-3 wt\%) of $\mathrm{Eu}^{3+}$ 
using solid state melting and quenching technique. Bulk density measurement using Archimedes principle, X-ray diffraction (XRD), fourier transform infrared spectroscopy (FTIR), and field emission scanning electron microscopy (FE-SEM) with energy dispersive X-ray (EDX) was used to investigate the effects of sintering temperature and the role played by the $\mathrm{Eu}^{3+}$ ion on the structural and morphological properties of the doped willemite-based glass ceramic samples. To the best of our knowledge, $\mathrm{Eu}_{2} \mathrm{O}_{3}$ doped willemite-based glass ceramic using waste material has not been reported yet, which was another motivation for this research.

\section{Experimental Procedure}

$\mathrm{Eu}_{2} \mathrm{O}_{3}$ doped willemite-based glass ceramic samples were prepared by solid state melting and quenching technique. High purity zinc oxide ( $\mathrm{ZnO})$ (99.99\%, Aldrich) powders and soda lime silica (SLS) glass waste powders were mixed together to produce the willemite-based glass ceramic. The SLS glass waste was chosen from the same brand from soya bean bottles. In order to produce the SLS glass powders, the SLS glass was crushed into powder form. The powders were blended in a ball-mill uniformly for $24 \mathrm{~h}$ to produce a mixture of powders containing $50 \mathrm{wt} \% \mathrm{ZnO}$ and $50 \mathrm{wt} \%$ SLS glass. The mixture was melted at $1400^{\circ} \mathrm{C}$ for $3 \mathrm{~h}$ and then quenched in water to form glass frits. The glass frits were dried in air for 1 day and were then crushed into powders to the size of $45 \mu \mathrm{m}$ using a specific sieve. After that, the powders were sintered at $900^{\circ} \mathrm{C}$ for $4 \mathrm{~h}$ to produce willemite. In doping process, $\mathrm{Eu}_{2} \mathrm{O}_{3}$ powder ranging from 1 to $3 \mathrm{wt} \%$ was doped into the willemite. In order to obtain mixed powders, the milling process was carried out for $24 \mathrm{~h}$. The mixed powders were uniaxially pressed into pellets of $13 \mathrm{~mm}$ in diameter and $2 \mathrm{~mm}$ in thickness with an applied load of 3.5 tons for $2 \mathrm{~min}$ using polyvinyl alcohol (PVA) as the binders. The soft green pellets were then sintered at $600,700,800,900$, and $1000^{\circ} \mathrm{C}$ for $4 \mathrm{~h}$ in the air using a conventional furnace. Archimedes principle with water as the fluid medium was used to measure the bulk density of the samples.

Structural changes of the compact samples were studied by XRD modeled Philips X'PERT MPD using a filtered $\mathrm{Cu}-$ $\mathrm{K} \alpha$ radiation $(\lambda=0.1542 \mathrm{~nm})$ in a wide range of $2 \theta\left(10^{\circ}<\right.$ $2 \theta<90^{\circ}$ ). The average crystallite size of all the samples was determined from full-width half-maximum (FWHM) of the reflection of major intensity peak in the XRD patterns using Debye Scherrer's formula:

$$
D=\frac{0.94 \lambda}{\beta \cos \theta},
$$

where $\lambda$ is the wavelength of the incident $\mathrm{X}$-ray; $\beta$ the fullwidth at half-maxima; and $\theta$ Bragg's diffraction angle. Functional groups of the samples were measured in the range of $360-1000 \mathrm{~cm}^{-1}$ using a Perkin-Elmer $1752 X$ spectrophotometer (Waltham, MA) using $\mathrm{KBr}$ disc method. Morphological observations were performed using a Fe-SEM FEI NOVA NanoSEM 230 machine equipped with EDX and the grain size was measured using mean linear intercept method.

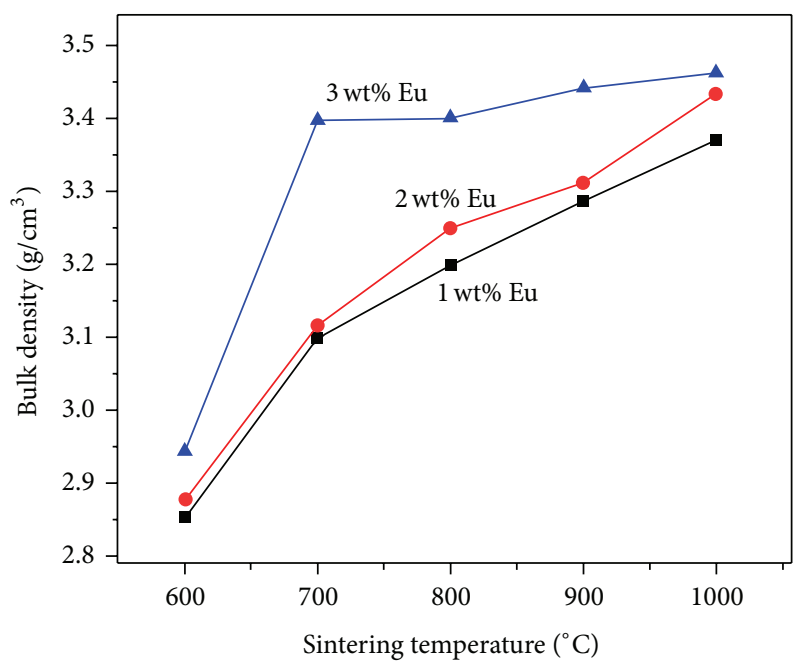

Figure 1: Bulk density of $\mathrm{Eu}_{2} \mathrm{O}_{3}$ doped willemite-based glass ceramic as a function of sintering temperature.

\section{Results and Discussion}

3.1. Density and Linear Shrinkage. Figure 1 shows the bulk density of $\mathrm{Eu}_{2} \mathrm{O}_{3}$ doped willemite with different weight percentage ( $\mathrm{wt} \%$ ) of $\mathrm{Eu}^{3+}$ sintered from 600 to $1000^{\circ} \mathrm{C}$ for $4 \mathrm{~h}$. The graph revealed an increase in the bulk density with increasing of the sintering temperature, with the highest density of $3.37 \mathrm{~g} / \mathrm{cm}^{3}$ for the samples sintered at $1000^{\circ} \mathrm{C}$ for $4 \mathrm{~h}$. It is mainly due to the decrease in total fractional porosity of the sample with the increase in sintering temperature. This value was compared favourably with the theoretical density of $3.90 \mathrm{~g} / \mathrm{cm}^{3}$ [18]. Hence the bulk density achieved using the solid state melting and quenching method was found to be $86.41 \%$ of the average theoretical density. The result of obtaining the high bulk density value without any sintering aid is interesting. Figure 2 shows the results of linear shrinkage of the pellets according to sintering temperature. There was a significant increase with the increasing in the sintering temperature.

3.2. X-Ray Diffraction (XRD). The XRD patterns of willemite and $\mathrm{Eu}_{2} \mathrm{O}_{3}$ doped willemite sintered in the temperature range from $600^{\circ} \mathrm{C}$ to $1000^{\circ} \mathrm{C}$ for $4 \mathrm{~h}$ are presented in Figures 3 and 4 . The observed peaks in these diffractograms were indexed to the rhombohedral willemite structure $[19,20]$. All peaks in the doped samples were shifted towards higher $2 \theta$ compared to the undoped samples. In common the shift towards higher $2 \theta$ values shows a slight reduction in the $d$ spacing values. This was to be expected since $\mathrm{Zn}^{2+}(0.74 \AA)$ ionic radius differs slightly from the $\mathrm{Eu}^{3+}(0.947 \AA)$ ionic radii [21]. The peak shifting might also be credited to the lattice mismatching, lattice distortion, strain of the crystal, and finite size effect. By referring to the XRD patterns, it was observed that crystal structure of the samples did not change and the peak difference was not much with the increase in the weight percentage of $\mathrm{Eu}^{3+}$. By applying Scherrer's formula and considering FWHM of the diffraction peaks, 


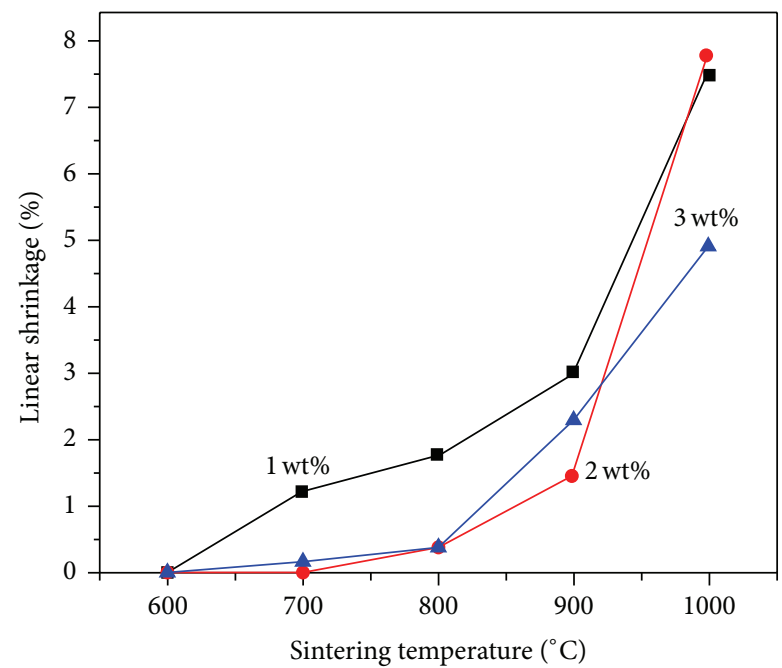

FIGURE 2: A variation of sintering temperature with linear shrinkage of $\mathrm{Eu}_{2} \mathrm{O}_{3}$ doped willemite-based glass ceramic.

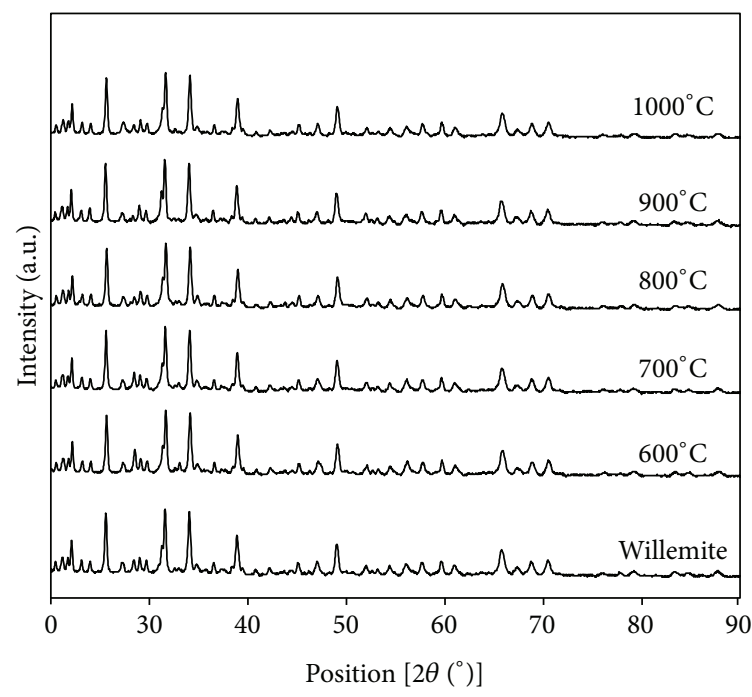

FIGURE 3: XRD patterns of willemite and $3 \mathrm{wt} \% \mathrm{Eu}_{2} \mathrm{O}_{3}$ doped willemite samples sintered at various temperatures for $4 \mathrm{~h}$.

average crystallite size of the pure willemite and $\mathrm{Eu}_{2} \mathrm{O}_{3}$ doped willemite samples sintered at various temperatures was calculated. Table 1 shows the value of crystallite size of each sample. Higher sintering temperature would increase atomic mobility and this would cause grain growth, which results in a better crystallinity. The $\mathrm{Eu}_{2} \mathrm{O}_{3}$ doped willemite samples show a variation of size, ranging from 44.30 to $53.14 \mathrm{~nm}$.

3.3. Fourier Transform Infrared Spectroscopy (FTIR). FTIR spectra of samples sintered at different temperatures are shown in Figures 5 and 6 . The series of all detected infrared absorption bands are summarized in Table 2 . These measurements were made to make a comparison between the experimental data that was gained in the present work with the previous research [22-25]. FTIR spectra of the glass-ceramic

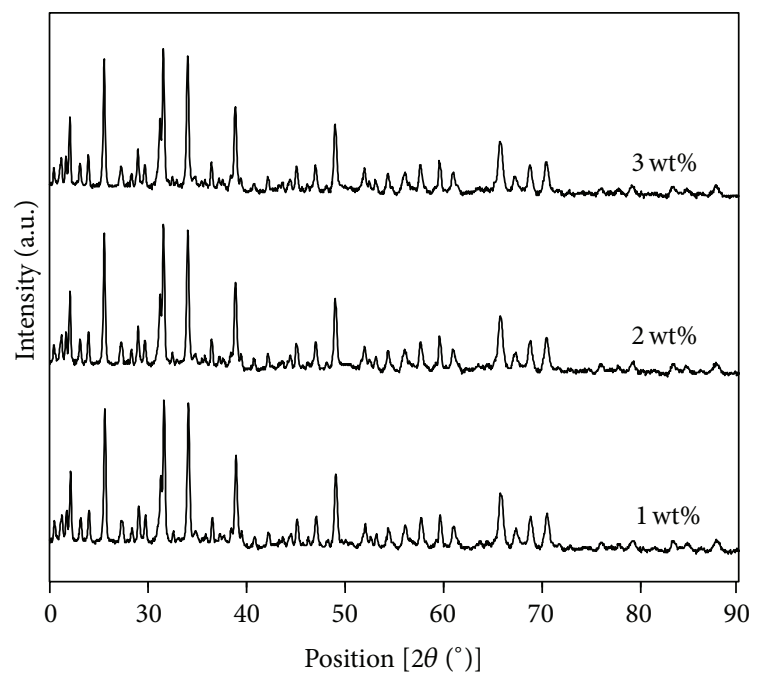

FIGURE 4: XRD patterns of various percentages of $\mathrm{Eu}_{2} \mathrm{O}_{3}$ doped willemite samples sintered at $1000^{\circ} \mathrm{C}$ for $4 \mathrm{~h}$.

TABLE 1: Average crystallite size of willemite and $3 \mathrm{wt} \% \mathrm{Eu}_{2} \mathrm{O}_{3}$ doped willemite-based glass ceramics.

\begin{tabular}{lc}
\hline Samples & Crystallite size $(\mathrm{nm})$ \\
\hline Willemite & 53.14 \\
$600^{\circ} \mathrm{C}$ & 44.30 \\
$700^{\circ} \mathrm{C}$ & 53.14 \\
$800^{\circ} \mathrm{C}$ & 53.14 \\
$900^{\circ} \mathrm{C}$ & 44.31 \\
$1000^{\circ} \mathrm{C}$ & 53.14 \\
\hline
\end{tabular}

matrix, $\mathrm{Zn}_{2} \mathrm{SiO}_{4}: \mathrm{Eu}_{2} \mathrm{O}_{3}$, consisted of eight wide and strong absorption bands placed at $459 \mathrm{~cm}^{-1}, 576 \mathrm{~cm}^{-1}, 615 \mathrm{~cm}^{-1}$, $697 \mathrm{~cm}^{-1}, 865 \mathrm{~cm}^{-1}, 901 \mathrm{~cm}^{-1}, 932 \mathrm{~cm}^{-1}$, and $978 \mathrm{~cm}^{-1}$. It has been known that metal oxide vibrations would occur at wavenumber below $1000 \mathrm{~cm}^{-1}$. The peak in the lower wavenumber at $459 \mathrm{~cm}^{-1}$ was attributed to the symmetric stretching of $\mathrm{SiO}_{4}$ group and $\mathrm{Eu}_{2} \mathrm{O}_{3}$ [26]. The band position located at $576 \mathrm{~cm}^{-1}$ was due to the $\mathrm{Si}-\mathrm{O}$ bending vibration modes [27]. The peak at $615 \mathrm{~cm}^{-1}$ was assigned to the asymmetric stretching vibration $\mathrm{ZnO}_{4}$ group. The bands that were present at $697,865,901,932$, and $978 \mathrm{~cm}^{-1}$ were corresponded to the symmetric stretching vibrations of the $\mathrm{Si}-\mathrm{O}$ bonding. It was found that as the sintering temperature increased from 600 to $1000^{\circ} \mathrm{C}$, there was an increase in the intensity of the IR bands.

3.4. Field Emission Scanning Electron Microscopy (FE-SEM). Figure 7 depicts the FE-SEM images of $\mathrm{Eu}_{2} \mathrm{O}_{3}$ doped willemite-based glass ceramics. The particle size was seen to increase after an increase in the sintering temperature. In lower temperature range $\left(600-800^{\circ} \mathrm{C}\right)$ the crystallized grains were aggregated and were irregular in shape. When the sintering temperature was increased to $900^{\circ} \mathrm{C}$, surface 


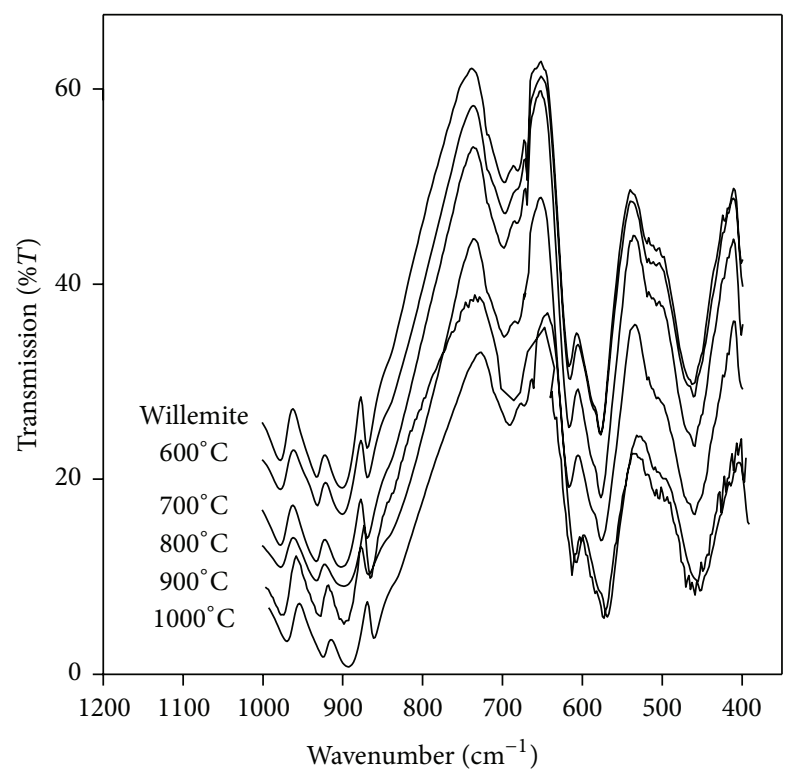

FIGURE 5: FTIR spectra of pure willemite and $\mathrm{Eu}_{2} \mathrm{O}_{3}$ doped willemite samples sintered at various temperatures and doped with different weight percentages of $\mathrm{Eu}^{3+}$.

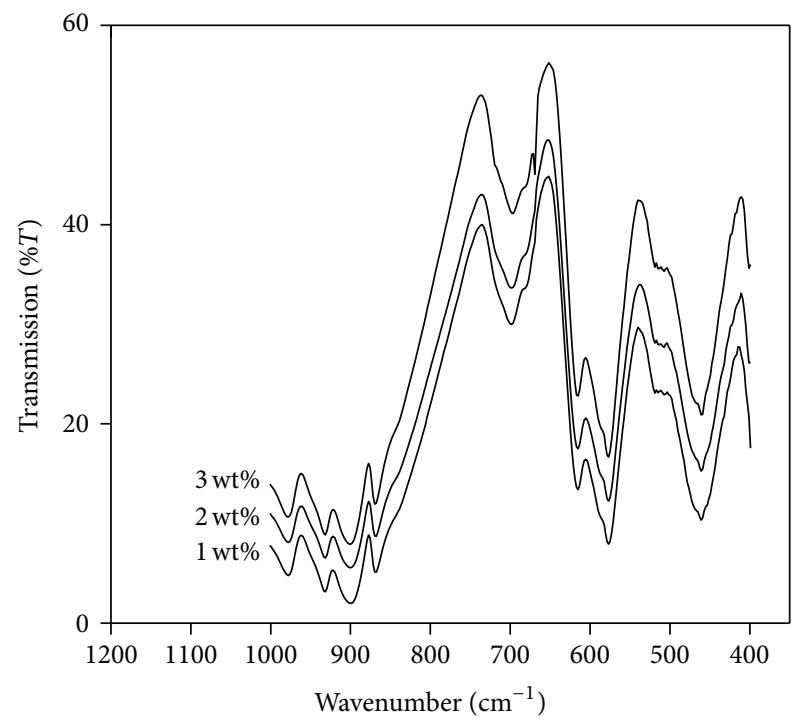

FIGURE 6: FTIR spectra of various percentages of $\mathrm{Eu}_{2} \mathrm{O}_{3}$ doped willemite samples sintered at $1000^{\circ} \mathrm{C}$ for $4 \mathrm{~h}$.

morphology of the sample became granular and it showed an initial stage of homogeneous distribution in shape, as shown in Figure 7(d). After increasing the temperature to $1000^{\circ} \mathrm{C}$, the grains that were rectangular-like clear were present. The grain size was increased during sintering as a result of grain growth. A grain size distribution graph of the samples is presented in Figure 8 while Table 3 shows the variation in the grain size of the samples. These results confirmed the increase of grain size along with sintering. The presence of $\mathrm{Eu}_{2} \mathrm{O}_{3}$ in the willemite matrix was confirmed by Fe-SEM-EDX analysis as shown in Figure 9. The EDX spectra showed clearly the peaks of $\mathrm{Zn}$,
TABLE 2: FTIR transmission features and respective assignment for $\mathrm{Eu}_{2} \mathrm{O}_{3}$ doped willemite sintered at various temperatures and different weight percentages.

\begin{tabular}{|c|c|}
\hline $\begin{array}{l}\text { Wavenumber } \\
\left(\mathrm{cm}^{-1}\right)\end{array}$ & Assignment \\
\hline $400-500$ & $\mathrm{Eu}_{2} \mathrm{O}_{3}$ vibration \\
\hline 459 & $\mathrm{Si}-\mathrm{O}$ symmetric stretching vibration in $\mathrm{SiO}_{4}$ units \\
\hline 576 & $\begin{array}{c}\mathrm{Zn}-\mathrm{O} \text { symmetric stretching vibration in } \mathrm{ZnO}_{4} \\
\text { units }\end{array}$ \\
\hline 615 & $\begin{array}{l}\mathrm{Zn}-\mathrm{O} \text { asymmetric stretching vibration in } \mathrm{ZnO}_{4} \\
\text { units }\end{array}$ \\
\hline 697 & $\mathrm{Si}-\mathrm{O}$ bond vibration \\
\hline 865 & Si-O symmetric stretching vibration \\
\hline $901-932-978$ & $\mathrm{Si}-\mathrm{O}$ asymmetric stretching vibration \\
\hline
\end{tabular}

TABLE 3: Grain size of $3 \mathrm{wt} \% \mathrm{Eu}_{2} \mathrm{O}_{3}$ doped willemite-based glass ceramics sintered at different temperatures for $4 \mathrm{~h}$.

\begin{tabular}{lc}
\hline Samples $\left({ }^{\circ} \mathrm{C}\right)$ & Grain size $(\mathrm{nm})$ \\
\hline 600 & 374.3 \\
700 & 489.3 \\
800 & 534.5 \\
900 & 862.9 \\
1000 & 963.4 \\
\hline
\end{tabular}

$\mathrm{O}, \mathrm{Si}, \mathrm{Al}$, and $\mathrm{Eu}$. The detection of $\mathrm{Au}$ peak in the sample was due to sputtering of the sample's surface with gold for conduction to provide clearer viewing. The Al peak was due to the utilization of SLS glass from the waste material. 


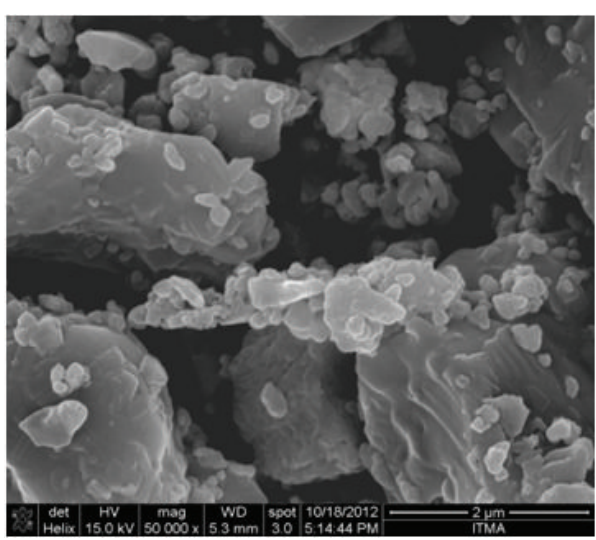

(a)

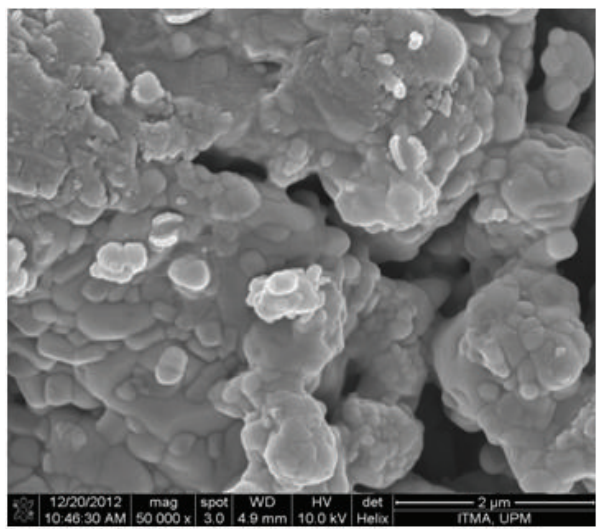

(c)

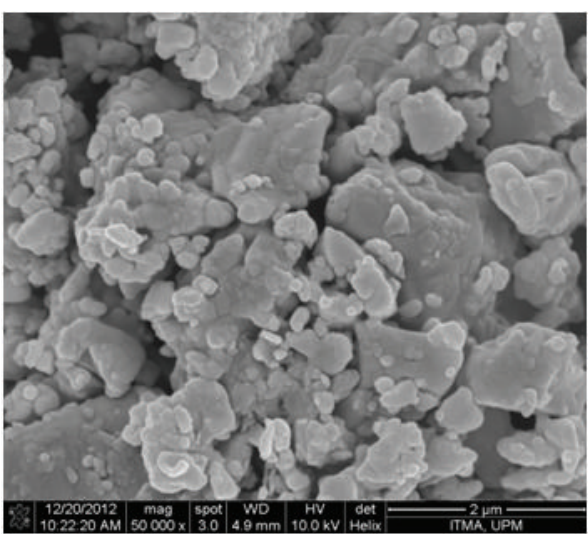

(b)

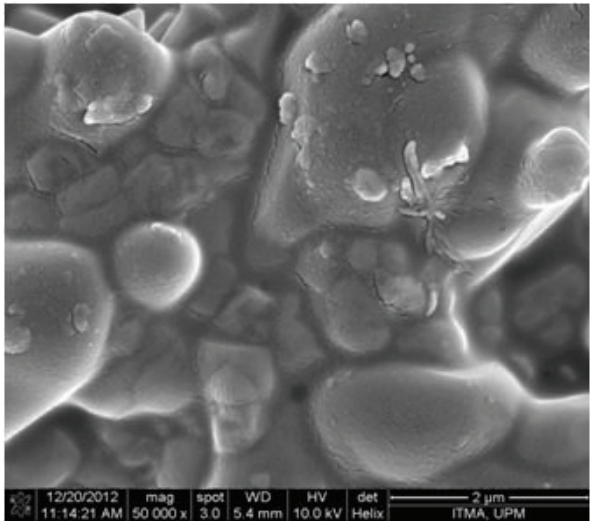

(d)

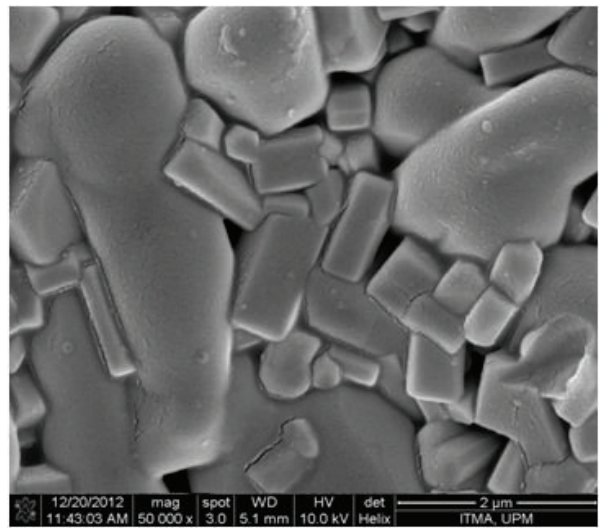

(e)

Figure 7: FE-SEM micrographs of $3 \mathrm{wt} \% \mathrm{Eu}_{2} \mathrm{O}_{3}$ doped willemite samples sintered at (a) $600^{\circ} \mathrm{C}$, (b) $700^{\circ} \mathrm{C}$, (c) $800^{\circ} \mathrm{C}$, (d) $900^{\circ} \mathrm{C}$, and (e) $1000^{\circ} \mathrm{C}$ for $4 \mathrm{~h}$.

\section{Conclusion}

In this study, the $\mathrm{Eu}_{2} \mathrm{O}_{3}$ doped willemite-based glass ceramic samples have been successfully prepared using the solid state melting and quenching technique. Bulk density of the samples was increased with the increase in the sintering temperatures and doping of various weight percentages of the
$\mathrm{Eu}^{3+}$. The XRD spectra indicated the presence of rhombohedral phase of willemite compounds in the pure and doped willemite samples sintered at $1000^{\circ} \mathrm{C}$ for $4 \mathrm{~h}$. The FE-SEM micrographs showed an increase in the grain size from 374 to $963 \mathrm{~nm}$ when the sintering temperature was increased. The chemical composition of the samples was also successfully investigated using the FE-SEM-EDX analysis. 


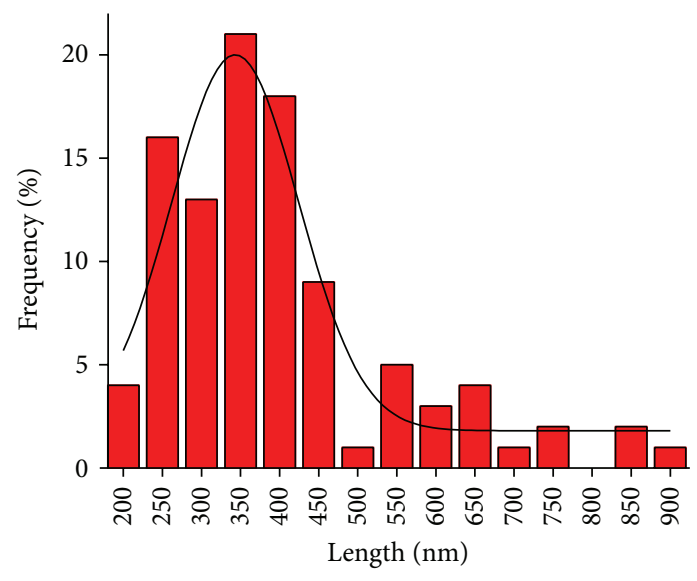

Grain size distribution

— Gauss fit

(a)

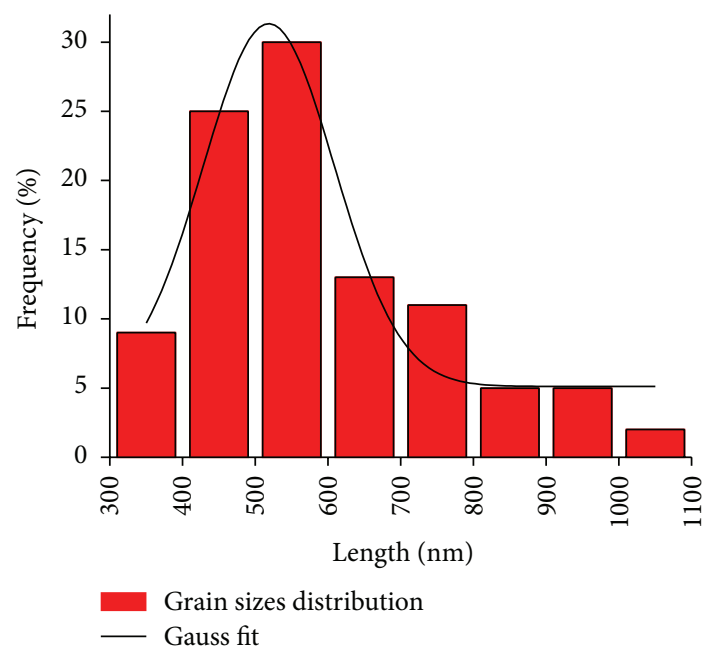

(c)

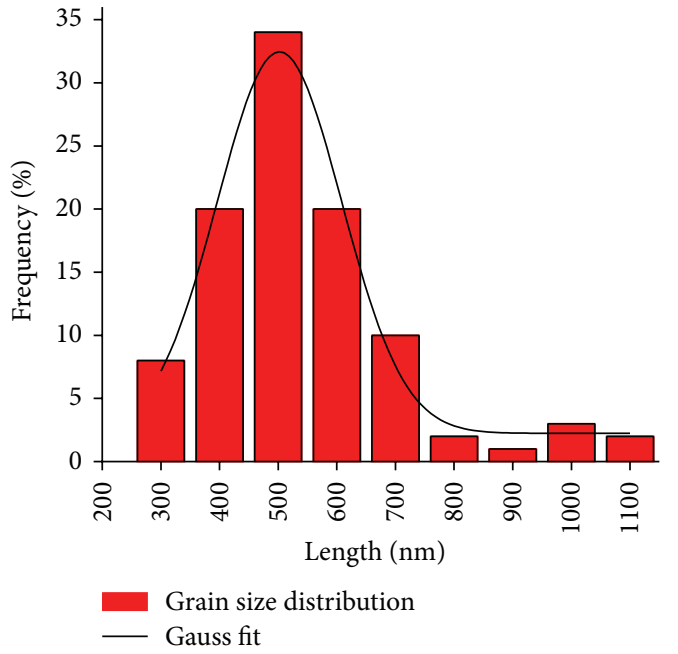

(b)

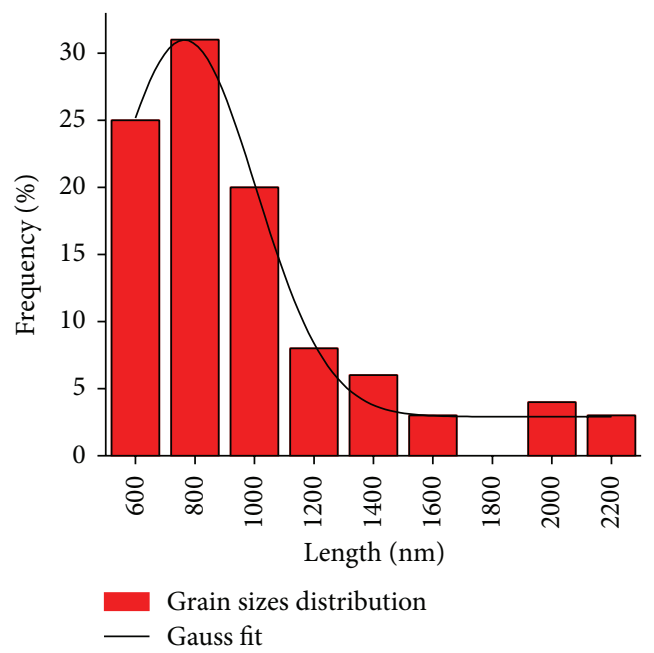

(d)

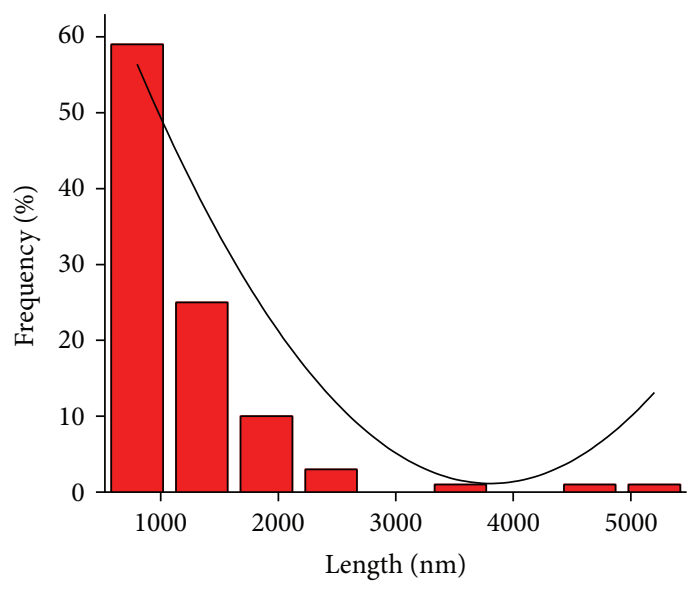

Grain sizes distribution - Gauss fit

(e)

Figure 8: Grain size distribution of $3 \mathrm{wt} \% \mathrm{Eu}_{2} \mathrm{O}_{3}$ doped willemite samples sintered at (a) $600^{\circ} \mathrm{C}$, (b) $700^{\circ} \mathrm{C}$, (c) $800^{\circ} \mathrm{C}$, (d) $900^{\circ} \mathrm{C}$, and (e) $1000^{\circ} \mathrm{C}$ for $4 \mathrm{~h}$. 

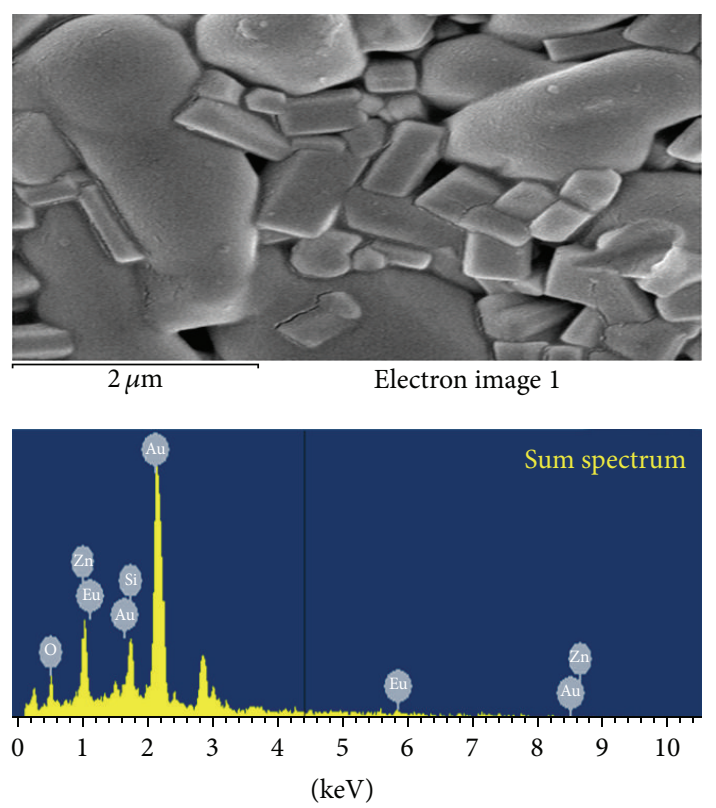

Full scale 520 cts cursor: 4.412 (12 cts)

Figure 9: Microstructures of $3 \mathrm{wt} \% \mathrm{Eu}_{2} \mathrm{O}_{3}$ doped willemite samples sintered at $1000^{\circ} \mathrm{C}$ for $4 \mathrm{~h}$ where the EDX analysis was performed.

\section{Conflict of Interests}

The authors declare that there is no conflict of interests regarding the publication of this paper.

\section{Acknowledgments}

The authors gratefully acknowledge the financial support from the Malaysian Ministry of Higher Education (MOHE) through the Exploratory Research Grant Scheme (5527189). One of the authors (W. F. Lim) would like to thank the financial support from the Universiti Putra Malaysia Postdoctoral Fellowship.

\section{References}

[1] G. Yoldjian, "The use of rare earths in ceramics," Journal of The Less-Common Metals, vol. 111, no. 1-2, pp. 17-22, 1985.

[2] S. A. Baldacim, C. Santos, O. M. M. Silva, and C. R. M. Silva, "Ceramics composites $\mathrm{Si}_{3} \mathrm{~N}_{4}-\mathrm{SiC}_{(w)}$ containing rare earth concentrate (CRE) as sintering aids," Materials Science and Engineering A, vol. 367, no. 1-2, pp. 312-316, 2004.

[3] M. Inoue, H. Otsu, H. Kominami, and T. Inui, "Glycothermal synthesis of rare earth aluminium garnets," Journal of Alloys and Compounds, vol. 226, no. 1-2, pp. 146-151, 1995.

[4] R. Terao, J. Tatami, T. Meguro, and K. Komeya, "Fracture behavior of AlN ceramics with rare earth oxides," Journal of the European Ceramic Society, vol. 22, no. 7, pp. 1051-1059, 2002.

[5] C. Xu and X. Ai, "Particle dispersed ceramic composite reinforced with rare earth additions," International Journal of Refractory Metals and Hard Materials, vol. 19, no. 2, pp. 85-88, 2001.
[6] V. C. Chaudhari, R. H. Patil, M. G. Patil, and C. S. Shalgonkar, "Electroluminescence spectra and excitation mechanism of $(\mathrm{Zn}, \mathrm{Cd}) \mathrm{S}$ thick films doped with various metallic and rare earth ions," Materials Chemistry and Physics, vol. 59, no. 2, pp. 162-167, 1999.

[7] S. G. Romanov, A. V. Fokin, and R. M. de la Rue, "Eu ${ }^{3+}$ emission in an anisotropic photonic band gap environment," Applied Physics Letters, vol. 76, no. 13, pp. 1656-1658, 2000.

[8] G. Blasse and B. C. Grabmaier, Luminescent Materials, Springer, New York, NY, USA, 1994.

[9] W. H. Yoon and S. Shionoya, Eds., Phosphor Handbook, CRC Press, Boca Raton, Fla, USA, 1998.

[10] A. Polman, "Erbium implanted thin film photonic materials," Journal of Applied Physics, vol. 82, no. 1, pp. 1-39, 1997.

[11] A. Patra, E. Sominska, S. Ramesh et al., "Sonochemical preparation and characterization of $\mathrm{Eu}_{2} \mathrm{O}_{3}$ and $\mathrm{Tb}_{2} \mathrm{O}_{3}$ doped in and coated on silica and alumina nanoparticles," The Journal of Physical Chemistry B, vol. 103, no. 17, pp. 3361-3365, 1999.

[12] W. Lü, Z. Hao, X. Zhang, Y. Luo, X. Wang, and J. Zhang, "Tunable full-color emitting $\mathrm{BaMg}_{2} \mathrm{Al}_{6} \mathrm{Si}_{9} \mathrm{O}_{30}: \mathrm{Eu}^{2+}, \mathrm{Tb}^{3+}, \mathrm{Mn}^{2+}$ phosphors based on energy transfer," Inorganic Chemistry, vol. 50, no. 16, pp. 7846-7851, 2011.

[13] S. Ekambaram, K. C. Patil, and M. Maaza, "Synthesis of lamp phosphors: facile combustion approach," Journal of Alloys and Compounds, vol. 393, no. 1-2, pp. 81-92, 2005.

[14] B. S. Tsai, Y. H. Chang, and Y. C. Chen, "Nanostructured red-emitting $\mathrm{MgGa}_{2} \mathrm{O}_{4}: \mathrm{Eu}^{3+}$ phosphors," Journal of Materials Research, vol. 19, no. 5, pp. 1504-1508, 2004.

[15] C.-H. Wen, S.-Y. Chu, and C.-K. Wen, "Polarization dependence of the luminescence properties of the erbium doped $\mathrm{KNbO}_{3}$ ferroelectric ceramics," Integrated Ferroelectrics, vol. 69, pp. 267-275, 2005.

[16] G. T. Chandrappa, S. Ghosh, and K. C. Patil, "Synthesis and properties of Willemite, $\mathrm{Zn}_{2} \mathrm{SiO}_{4}$, and $\mathrm{M}^{2+}: \mathrm{Zn}_{2} \mathrm{SiO}_{4}(\mathrm{M}=\mathrm{Co}$ and $\mathrm{Ni}$ )," Journal of Materials Synthesis and Processing, vol. 7, no. 5, pp. 273-279, 1999.

[17] A. Forés, M. Llusar, J. A. Badenes, J. Calbo, M. A. Tena, and G. Monrós, "Cobalt minimisation in willemite $\left(\mathrm{Co}_{x} \mathrm{Zn}_{2-x} \mathrm{SiO}_{4}\right)$ ceramic pigments," Green Chemistry, vol. 2, no. 3, pp. 93-100, 2000.

[18] http://webmineral.com/data/Willemites.html.

[19] Q. Lu, P. Wang, and J. Li, "Structure and luminescence properties of $\mathrm{Mn}$-doped $\mathrm{Zn}_{2} \mathrm{SiO}_{4}$ prepared with extracted mesoporous silica," Materials Research Bulletin, vol. 46, no. 6, pp. 791-795, 2011.

[20] Y. Lv, R.-Z. Zuo, and Z.-X. Yue, "Structure and microwave dielectric properties of $\mathrm{Ba}_{3}\left(\mathrm{VO}_{4}\right)_{2}-\mathrm{Zn}_{2-x} \mathrm{SiO}_{4-x}$ ceramic composites," Materials Research Bulletin, vol. 48, no. 6, pp. 2011-2017, 2013.

[21] R. D. Shannon, "Revised effective ionic radii and systematic studies of interatomic distances in halides and chalcogenides," Acta Crystallographica A, vol. 32, no. 5, pp. 751-767, 1976.

[22] A. Shaim, M. Et-Tabirou, L. Montagne, and G. Palavit, "Role of bismuth and titanium in $\mathrm{Na}_{2} \mathrm{O}-\mathrm{Bi}_{2} \mathrm{O}_{3}-\mathrm{TiO}_{2}-\mathrm{P}_{2} \mathrm{O}_{5}$ glasses and a model of structural units," Materials Research Bulletin, vol. 37, no. 15, pp. 2459-2466, 2002.

[23] Q. Chen, M. Ferraris, D. Milanese, Y. Menke, E. Monchiero, and G. Perrone, "Novel Er-doped $\mathrm{PbO}$ and $\mathrm{B}_{2} \mathrm{O}_{3}$ based glasses: investigation of quantum efficiency and non-radiative transition probability for $1.5 \mu \mathrm{m}$ broadband emission fluorescence," Journal of Non-Crystalline Solids, vol. 324, no. 1-2, pp. 12-20, 2003. 
[24] R. Iordanova, Y. Dimitriev, V. Dimitrov, S. Kassabov, and D. Klissurski, "Glass formation and structure in the $\mathrm{V}_{2} \mathrm{O}_{5}-\mathrm{Bi}_{2} \mathrm{O}_{3}$ $\mathrm{Fe}_{2} \mathrm{O}_{3}$ glasses," Journal of Non-Crystalline Solids, vol. 204, no. 2, pp. 141-150, 1996.

[25] G. L. J. Trettenhahn, G. E. Nauer, and A. Neckel, "Vibrational spectroscopy on the $\mathrm{PbO}-\mathrm{PbSO}_{4}$ system and some related compounds: part 1. Fundamentals, infrared and Raman spectroscopy," Vibrational Spectroscopy, vol. 5, no. 1, pp. 85-100, 1993.

[26] S. Rada, A. Dehelean, and E. Culea, "FTIR and UV-VIS spectroscopy investigations on the structure of the europiumlead-tellurate glasses," Journal of Non-Crystalline Solids, vol. 357, no. 16-17, pp. 3070-3073, 2011.

[27] M. R. Ahsan and M. G. Mortuza, "Infrared spectra of $\mathrm{xCaO}_{(1-X-z)} \mathrm{SiO}_{2} \mathrm{zP}_{2} \mathrm{O}_{5}$ glasses," Journal of Non-Crystalline Solids, vol. 351, no. 27-29, pp. 2333-2340, 2005. 

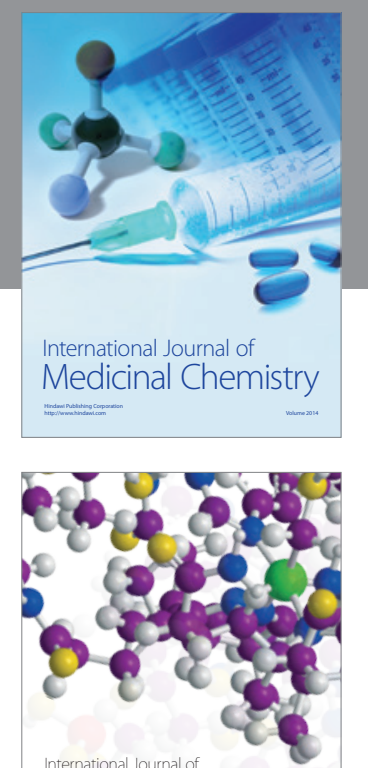

\section{Carbohydrate} Chemistry

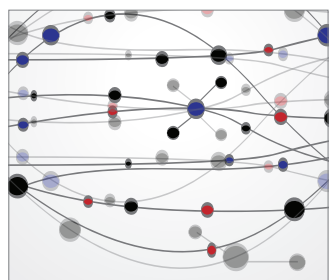

The Scientific World Journal
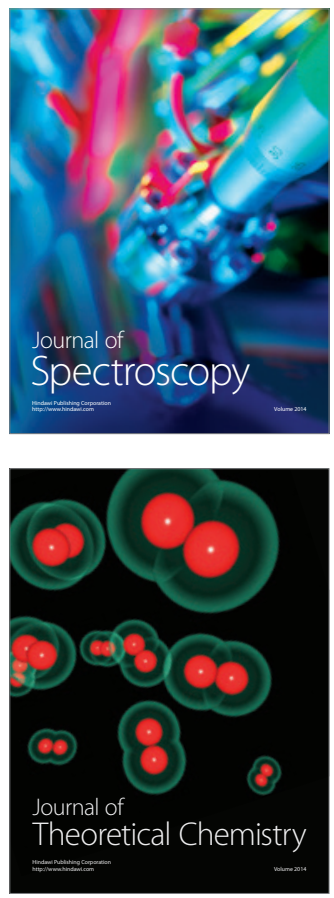
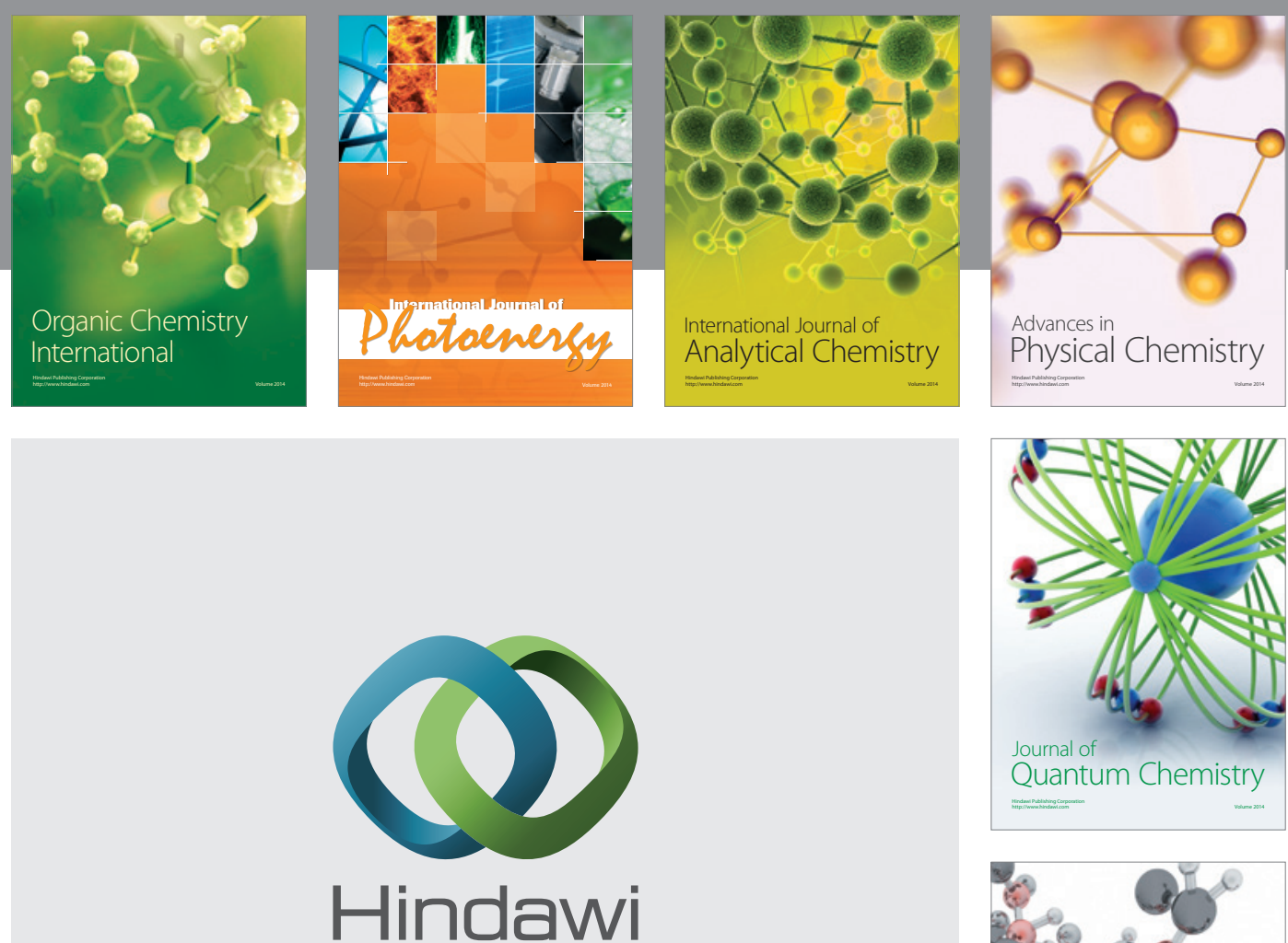

Submit your manuscripts at

http://www.hindawi.com

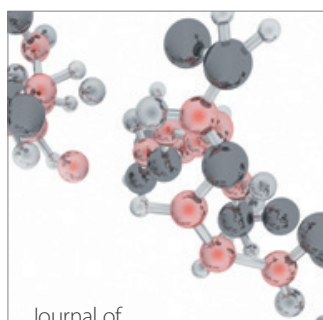

Analytical Methods

in Chemistry

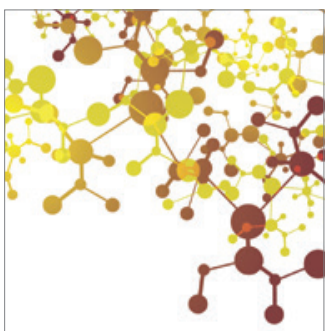

Journal of

Applied Chemistry

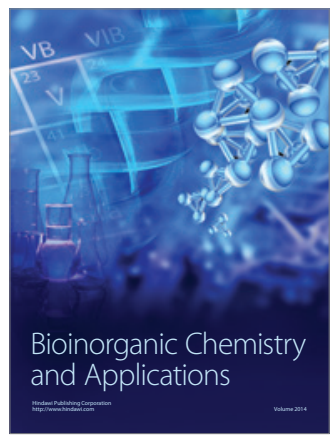

Inorganic Chemistry
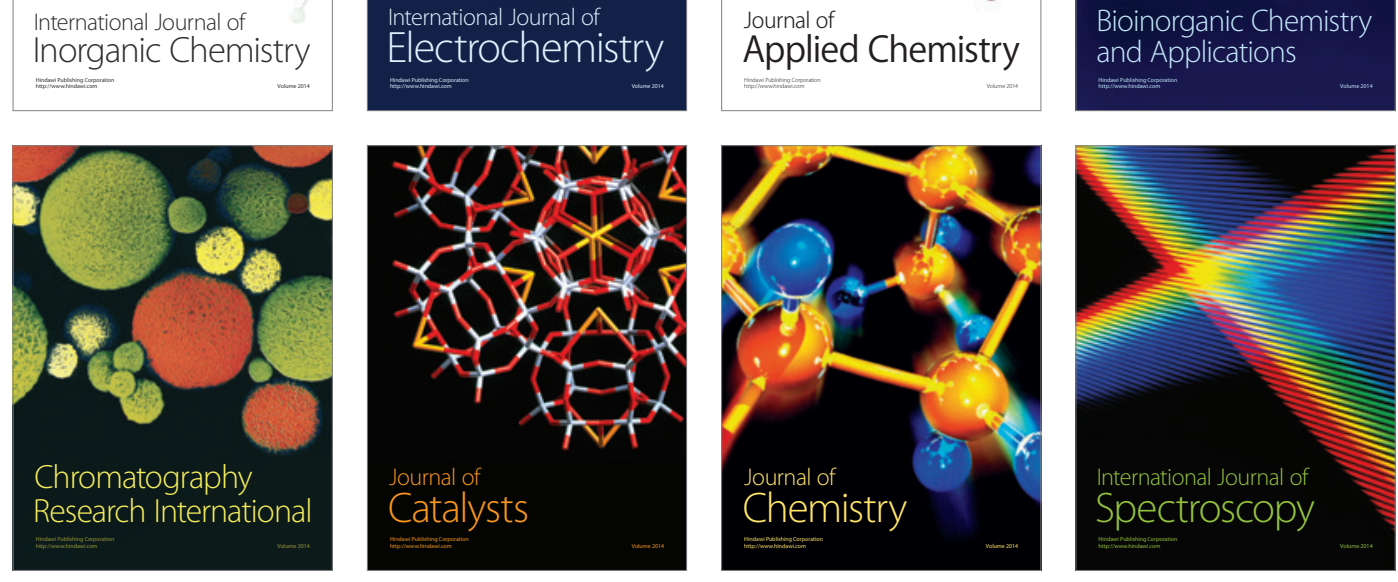